\title{
Psychological Barriers to Sustainable Dietary Patterns: Findings from Meat Intake Behaviour
}

\author{
Carlos Eduardo Lourenco ${ }^{1, *} \mathbb{\infty}$, Nadine Marques Nunes-Galbes ${ }^{2}{ }^{\infty}$, Riccardo Borgheresi ${ }^{1}{ }^{1}$, \\ Luciana Oranges Cezarino $^{3}{ }^{(1)}$, Flavio Pinheiro Martins ${ }^{4,5}$ and Lara Bartocci Liboni ${ }^{5}$
}

Citation: Lourenco, C.E.;

Nunes-Galbes, N.M.; Borgheresi, R.; Cezarino, L.O.; Martins, F.P.; Liboni,

L.B. Psychological Barriers to

Sustainable Dietary Patterns:

Findings from Meat Intake Behaviour. Sustainability 2022, 14, 2199. https:// doi.org/10.3390/su14042199

Academic Editor: Mario D’Amico

Received: 26 November 2021

Accepted: 2 February 2022

Published: 15 February 2022

Publisher's Note: MDPI stays neutral with regard to jurisdictional claims in published maps and institutional affiliations.

Copyright: (c) 2022 by the authors. Licensee MDPI, Basel, Switzerland. This article is an open access article distributed under the terms and conditions of the Creative Commons Attribution (CC BY) license (https:/ / creativecommons.org/licenses/by/ $4.0 /)$.
1 Getulio Vargas Foundation-FGV EAESP, São Paulo 01332-000, SP, Brazil; riccardoborgheresi@hotmail.com

2 Faculty of Public Health, University of São Paulo_FSP_USP, São Paulo 01246-904, SP, Brazil; nadine.m.nunes@gmail.com

3 BLISS Digital Impact, Venice Business School, Ca' Foscari University of Venice, 30123 Venice, Italy; luciana.cezarino@unive.it

4 School of Medicine of Ribeirao Preto, University of Sao Paulo-FMRP-USP, Ribeirão Preto 14049-900, SP, Brazil; fpmartins@usp.br

5 School of Economics, Business Administration and Accountability, University of Sao Paulo-FEA-RP-USP, Ribeirão Preto 14049-900, SP, Brazil; laraliboni@usp.br

* Correspondence: carlos.lourenco@fgv.br; Tel.: +55-11-3799-7750

\begin{abstract}
Sustainable diets are patterns that change consumer behaviour towards more balanced and plant-based habits. This study investigates the effect of individuals' predisposition to adopt sustainable diets while reducing meat intake by measuring their psychological proximity to meat. Using an online consumer-based platform, a cross-sectional survey collected responses from 497 individuals. Questionnaire items included 43 questions prospected from the literature, coded as practical and essential barriers and measured on a modified 7-point Likert scale. The results showed some paradoxes, as a high predisposition to adopt a sustainable diet coexists with a high predisposition to consume animal-based proteins. The main perceived barrier to adopting a plant-based diet was the enjoyment of eating meat, followed by the lack of information about plant-based diets. Barriers related to meat alternatives remained the highest above all the others. It confirms that, for local consumers, meat remains a usual option and is easier to prepare. When investigating the moderating effect of barriers on the predisposition to behaviours towards meat intake reduction, no effect was confirmed. However, we found a U-shaped moderating effect for plant-based meal increase, confirming the psychological proximity of the meat consumption effects under the lens of the Construal Level Theory and Transtheoretical Model. These findings call for further research on the effectiveness of measuring psychological barriers related to sustainable diet adoption.
\end{abstract}

Keywords: sustainable diets; dietary behaviour; meat intake; construal level theory; transtheoretical model; psychological barriers

\section{Introduction}

As society amplifies the discussions and practises on sustainability, the concept of sustainable diets is reaching a broader audience. Initially, it related only to the appropriate use of the environmental resources or diminishing the environmental impact along the food supply chain $[1,2]$. Sustainable diets have also expanded into new realms, such as human health and the perception of wellbeing, accessibility, safety, equity, and cultural adequacy, evolving to indicate how rich and vast the interconnection between sustainability and food systems could be.

Sustainable food consumption has gained traction among consumers [3] and relevance among multi-stakeholders [4]. It is paramount to connect the green-buying customer behaviours to the implications of these preferences in the food systems. Such choices supposedly condemn highly processed food products due to emerging buying patterns and 
increasing purchase intention towards more sustainable options [5]. However, investigating effective consumer selection towards more sustainable options remains a challenge [6], as the recognition of sustainability relevance does not translate to low carbon footprints [7], and individuals maintain psychological distance to the subject [8]. Therefore, to accelerate behavioural change towards more sustainable goals, it is necessary to increase the psychological proximity of consumers and the chances of diet acceptance.

This research focused on examining customers' behaviour of sustainable food consumption in the light of Construal Level Theory (CLT) and the Transtheoretical Model (TTM) framework. CLT is a relatively recent theory [9] that seeks to explain the judgement and choice referenced by the psychological representation of decision making to make predictions about the individual's choices [10]. According to the CLT, individuals use lower-level and concrete representations to represent psychologically close events and high-level and abstract representations to represent psychologically distant events [9].

On the other hand, TTM is one of the most used theories in behavioural change epistemology, including eating behaviour studies [11]. The model uses stages to integrate processes and principles of change from the dominant intervention theories and can also be called the "behavioural change stages model" [12]. According to the TTM, changing a behaviour is a process, which implies that each individual is at a different stage of change, indicating different levels of promptness to change. Behaviour changes influence consumers' personal dietary decisions, impacting the food industry and affecting multiple stakeholders in the entire supply chain, with a history of both collaborative and confrontational approaches [13]. Moreover, a deep understanding of customers' attitudes can provide insights into critical environmental-related decisions $[8,14]$ affecting producers, distributors and NGOs and ultimately reducing individual meat consumption [15].

The increasing growth of the human population enlarges the demand for food, which brings sound concern to the environmental pressure of food production [16] on ecosystem dimensions $[17,18]$. On the other hand, plenty of scientific evidence has associated the adoption of alternative dietary habits with diminishing greenhouse gas (GHG) emissions, deforestation and biodiversity loss [19]. Global adoption of a low-meat diet that meets nutritional recommendations for fruits, vegetables and caloric requirements is estimated to reduce diet-related GHGs by nearly $50 \%$ [4]. However, individuals have shown resistance to dietary changes. The willingness to adopt different habits occurs in stages, from a no adoption to full adoption [14], depending on consumers' preference [20]. Indeed, people are even more reluctant to change for some food groups, such as ruminant-derived food products, especially meat and dairy products [21,22]. Western societies are accustomed to meat consumption $[23,24]$, guided and validated by social norms. There are opportunities to link individual attitudes and behaviour towards food consumption with the overall impact of such decisions and their relation to environmental concerns [25]. Simultaneously, the ecological impact of individual food consumption seems like a distant fact for public perception with abstract implications [26,27].

Changes to the current production and consumption of goods and services are demanded in a supranational perspective to diminish the use of natural resources [4]. One immediate initiative to back up such claims is to articulate sustainable consumption on the demand side, to the point that the retail environment is transforming due to changes in customer preferences [28]. One of the most conspicuous changes is ecological and healthier food consumption behaviours $[29,30]$. Eating to save the planet is a known trend for conscious populations, which translates to dietary changes to reduce food carbon footprint and, thus, natural resources [31]. Moreover, additional benefits can be accrued since even moderate dietary changes to more environment-friendly diets can improve healthier food intake [32,33]. In addition to the clear self-benefits, persuading individuals to adopt dietary changes towards sustainable consumption positively impacts the entire food chain since more minor environmental problems will emerge from the whole food system-production, processing, distribution and consumption [14]. 
There is a vastness of antecedents to determining food choice, and choosing more ecological food is a difficult decision for customers due to all the different factors that must be considered [34]. An ever-growing body of knowledge addresses the combined effect of dietary shifts, food production systems and waste reduction [35]. People still perceive the impact of packaging disposal as more salient environmental aggression than meat consumption, which is an essential consideration for healthy and sustainable diets [22]. Meat consumption is also related to cultural norms that have been strengthened by more efficient meat supply chains, increasing availability and diminishing prices [24]. Furthermore, meat consumption is deeply embedded in Western culture [25]. In this scenario, understanding customers' decision patterns is essential to overcome attitudes and habits inconsistent with a more sustainable consumption (such as the plastic packaging versus the entire supply chain conundrum). Likewise, the appraisal of the barriers for converting attitudes to behaviour is paramount to attenuate resistances and influence consumer behaviour change [36].

Sustainable Healthy Diets are defined by the FAO as "dietary patterns that promote all dimensions of individuals' health and wellbeing; have low environmental pressure and impact; are accessible, affordable, safe and equitable; and are culturally acceptable" [4]. The concept of a sustainable diet is very complex and has a broad definition, ranging from breastfeeding to the consumption of unprocessed food. The concept comprises greenhouse gas emissions, water and land use and the preservation of biodiversity; the reduction of antibiotics and plastics; the reduction of food loss and waste; and a myriad of activities involved in food production [2]. To achieve Sustainable Healthy Diets by 2050, significant changes in today's prevailing food patterns will be necessary. New patterns will be required, such as doubling the consumption of fruits, vegetables, legumes and nuts, and reducing the global consumption of foods such as red meat by more than 50 percent [37]. In this sense, plant-based diets can be considered one of the fundamental practical bases of Sustainable Healthy Diets, although these are not only reduced to the plant-based concept [4].

Although a plant-based diet may not be perceived as a vegetarian, it still acts as one of the pillars of a sustainable and healthy diet $[4,38]$, acting as a stepwise scale, where veganism presents a zero to the consumption of animal origin food or ingredients. Vegetarianism intrinsically has many facets, which may be motivated by environmental, ethics and animal welfare aspects, among others [39]. In a similar way, healthy and sustainable dietary patterns rely not only on reducing the intake of animal-based food groups but also on broader aspects related to social, political and nutritional factors [40]. These are intricate processes that can complement each other such as the production logic, the prioritised food groups, processing, packaging and retail format [4,37].

Understanding the mental pathways of individuals concerning nutrition decisions is a dynamic and complex research area [41]. The present study objective is to investigate the effect of individuals' predisposition to adopt sustainable diets and to reduce or exclude meat intake, along with the consequences of the perception of barriers in moderating this relationship. The focus was on meat alternatives, dietary patterns and plant-based consumption in a population sample in Sao Paulo state, Brazil. We assessed sustainable diets at two levels, a milder meat minimisation with plant-based food adoption ("flexitarianism") and a more stringent meat avoidance perspective related to vegetarianism. However, despite such forward-looking self-regulation, we investigated if the local population is changing its dietary patterns with a focus on sustainability. The premise is that the predisposition of individuals to adopt meat alternatives do not (necessarily) translate into similar behaviour as a result of the effect of perceived barriers [42].

The possibility to progressively move to more sustainable food production due to changes in consumption habits is pronounced and logical but difficult to achieve. An increasing number of countries introduced sustainability considerations into their food policies, such as dietary guidelines, aiming to promote food and nutritional education to its population towards healthy and sustainable food patterns, although still moderately [16,43]. Most of these recommendations include the shift to a primarily plant-based diet and 
reducing red and processed meat intake [44,45]. In this sense, the Dietary Guidelines for Brazilian Population [46] is an avant-garde public policy initiative, with one of the highest Total Sustainability Scores [43].

\section{Framework Proposition and Hypothesis Design}

The TTM model proposes that, throughout this process, individuals go through five stages: 1-Precontemplation, represented by no recognition of a need for or interest in changing; 2-Contemplation, represented by reflection about changing; 3-Preparation, represented by the planning for changing; 4-Action, represented by the adoption of new habits; and 5-Maintenance, represented by the ongoing practice of the new behaviour [12]. CLT relates to the TTM in the sense that the greatest psychological distance corresponds to the earliest stages of the process of behaviour change.

We contend that the behavioural change in consumers could happen in two directions, the reduction in meat intake and the adoption of a healthier diet or a sustainable dietary pattern. Therefore, we propose the following hypothesis: predisposition is a stage of low psychological distance (stage 3-Preparation), representing the intent to change the circumstances in which it serves as a proxy (antecedent variable) to build our framework. So, we relate both results of consumer behaviour change (meat intake and sustainable dietary pattern) with the stimulus variable, the predisposition to change. Figure 1 depicts the structural model.
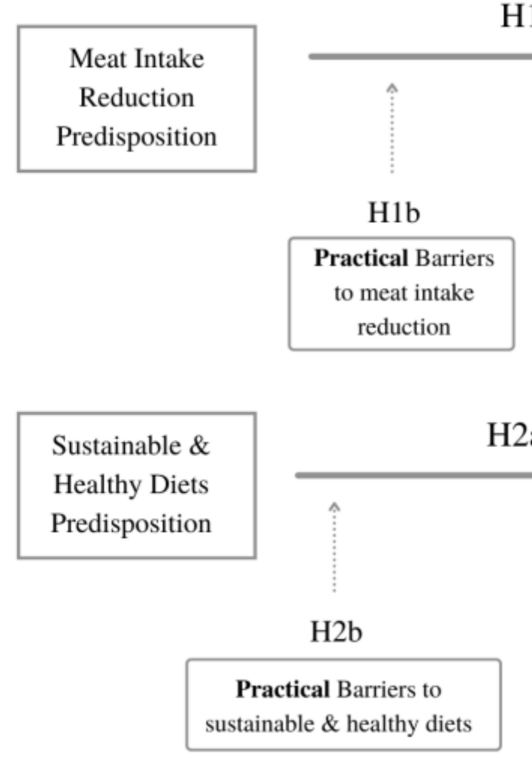

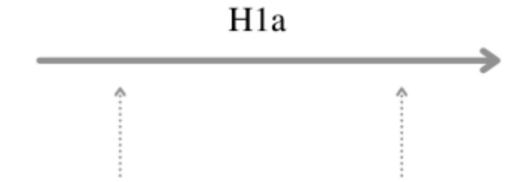

$\mathrm{H} 1 \mathrm{c}$

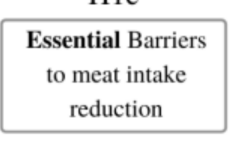

$\mathrm{H} 2 \mathrm{a}$

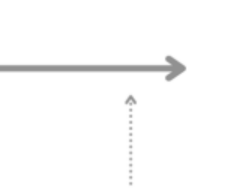

$\mathrm{H} 2 \mathrm{c}$

Essential Barriers to sustainable \& healthy diets

Figure 1. Framework for meat consumption reduction and sustainable diets adoption.

Hypothesis 1a (H1a). Higher predisposition to reduce meat consumption will have a positive influence on consumer behaviour towards reducing meat consumption.

Hypothesis 2a (H2a). Higher predisposition to sustainability will have a positive influence on consumer behaviour towards a sustainable and healthy dietary pattern.

Individuals make food choices that create dietary patterns under the influence of a range of social aspects and actors [47]. As often as food choices may seem arbitrary, they are symbolic, multifaceted, dynamic and complex. Those choices are not only in decision making but also in dietary behaviours, which involve multiple aspects of the relationship with food $[48,49]$. In dietary behaviour, external or internal factors are psychological barriers that may change the consumer's dietary choices. Consequently, there are barriers in dietary changes [42] that could interfere with the behaviour and predisposition to change. 
In this sense, barriers can moderate the attitudes towards meat intake and a sustainable dietary pattern [50].

It is possible to classify difficulties in different ways, such as practical, for example, related to work routine or food environment, and attitudinal, regarding beliefs and values [42], or even socio-demographic, regarding, for example, education level, gender or kids in the household $[50,51]$. Somehow, socio-demographic barriers relate to attitudinal impediments, permeating beliefs such as the increased need for animal-sourced protein food for both children and adults, imposing additional barriers for these demographic groups [51]. Considering that a more plant-based diet is one of the essential pillars of a sustainable and healthy diet [4,39], we used previous work [42,51], which has addressed perceived barriers to consuming a plant-based diet.

Lea et al. [42] investigated respondents' agreement with 27 selected practical and attitudinal barriers and compared the perception among gender, age and education level. Pohjolainen et al. [51] identified the perceived barriers that are most essential to consumers. Among different approaches in the literature, only a few recognised the genuine difficulties to adoption. Mainly, comparative analysis using different samples found no significant difference in the perception of a barrier. We coded 'practical barriers' as those barriers linked to attitudinal and practical dimensions [42], whereas 'essential barriers' as fundamental barriers [51]. This study modified the scales on the literature [42,51] to assess barriers related to plant-based diets and healthy and sustainable dietary patterns. We adapted the final scale using 21 different barriers, 12 from Lea et al. [42], 4 from Pohjolainen et al. [51] and 5 additional barriers to adopting sustainable diets. Figure 1 shows the moderating role of barriers between the predisposition and the consumer behaviour regarding both results, meat intake (H1b and $\mathrm{H} 1 \mathrm{c}$ ) and sustainable dietary patterns (H2b and $\mathrm{H} 2 \mathrm{c})$. Therefore, we propose the following hypothesis:

Hypothesis $\mathbf{1 b} \mathbf{( H 1 b )}$. The practical barriers mediate the relationship between predisposition and meat intake reduction.

Hypothesis 1c (H1c). The essential barriers mediate the relationship between predisposition and meat intake reduction.

Furthermore:

Hypothesis $\mathbf{2} \mathbf{b}(\mathbf{H} \mathbf{2} \mathbf{b})$. The practical barriers mediate the relationship between predisposition and sustainable dietary patterns.

Hypothesis 2c (H2c). The essential barriers mediate the relationship between predisposition and sustainable dietary patterns.

\section{Materials and Methods}

\subsection{Survey Design}

The questionnaire of this research was developed using questions that supported the hypotheses previously defined. The research scale came from Lea at al. [42] and Pohjolainen et al. [51]. The questionnaire was divided in 6 sections, namely, greetings and opt-in, sustainability and healthy diet behaviours, sustainability and healthy diets predisposition, meat intake reduction behaviour, meat intake reduction predisposition and final message.

The first section of the survey included a brief presentation of the research objectives and a confirmation term (opt-in) for participation. The questionnaire contained a second section about the knowledge and perceptions about sustainable food systems, a third section about predisposition of the relevance of sustainable behaviours, a fourth section on sustainable eating habits and practises (based on CLT) and a final section of potential barriers for the adoption of sustainable eating habits and practises (see Figure 1 for the theoretical framework) [52]. 
The questionnaire used a modified seven-point Likert scale since it is the most appropriate for surveys on consumer behaviour [53]. We measured behaviour by a scale of negative and positive conduct combined with a temporal indication, designated "behaviour adoption scale". Table 1 illustrates an example of the adoption scale.

Table 1. Behaviour adoption scale.

\begin{tabular}{ll}
\hline 1-7 Points Likert Scale & $\begin{array}{l}\text { Question: “Regarding Your Usual Intake of Animal-Based } \\
\text { Food, Have you Made Any of the Following Changes?" }\end{array}$ \\
\hline 1 & No, I have not \\
2 & No, but I would like to do so immediately \\
3 & No, but I'm getting ready to do it soon \\
4 & No, but I'm about to start soon \\
5 & Yes, I've been doing it up to six months, at least \\
6 & Yes, I have been doing it for a year at least \\
7 & Yes, I've been doing it for more than a year \\
\hline
\end{tabular}

To identify moderate meat reduction (flexitarianism) and meat avoidance (vegetarianism), we adapted the questions to include options for both decline in meat consumption along with complete exclusion (see items on page 9-“Questions regarding predisposition and behaviour about animal-based food consumption"). The questions and answers used in the study are available in Supplementary Material file.

\subsection{Data Collection}

We collected data on an exploratory, cross-sectional, self-reported survey [52], using a web-based consumer panel (MindMiners.com), interfacing users on a mobile application [54]. Consumer-based online platforms are growing in popularity and usage, including sustainable food-related issues [53]. The automated digital platform surveyed the consumers. Data contained only demographics and no reference to personal information.

There were 497 respondents living in the state of Sao Paulo, Brazil. Table 2 provides the primary respondent's profiles. Age of participants ranged from 18 to 69 years. Although there was some age dispersion in the sample, most of the respondents $(58 \%$ or $n=289)$ were 18 to 40 years old, albeit panel data ensure increased composition and data quality [55]. The sample was composed by respondents with the following dietary patterns: flexitarian $(10.9 \%)$, ovo-lacto vegetarian $(6.8 \%)$, vegetarian $(9.1 \%)$ and respondents without dietary changes $(73.2 \%)$.

\subsection{Data Analysis}

To assess the scales' validity (sensitivity and specificity), we intentionally chose consumers under the rigorous criteria of the research proposal and added additional questions to validate behaviour. In addition, we found no ideal translations for a few words because of a lack of equivalent concepts in Portuguese. These words allow for various possible partially equivalent semantic expressions [54]. After additional scrutiny, we conducted a pre-test, and 31 respondents answered the survey, which contained 43 items. Participants were academics and nutrition professionals-recruited to improve the scale technically - and individuals of the general population who assessed its fluidity and applicability. After adjustments to wording, we collected 497 valid responses and exported final data to a CSV file. We made the analysis using IBM SPSS AMOS 26 for the covariance-based structural equation modelling (CB-SEM) and R Commander (Rcmdr 2.6), running R 4.0.2 for the generalised linear models' moderation. Next, we ran tests for normality, linearity, homoscedasticity and multicollinearity procedures and analysed the data using descriptive statistics [55]. We observed no deviations, thus enabling the submission of all datasets to multivariate analysis. 
Table 2. Demographic and socioeconomic characteristics of the respondents $(n=497)$.

\begin{tabular}{ccc}
\hline & Participants (n) & Percentage (\%) \\
\hline Gender & 278 & \\
Female & 219 & 56.0 \\
Male & & 44.0 \\
Age & 149 & \\
18 to 30 & 140 & 30.0 \\
31 to 40 & 102 & 28.2 \\
41 to 50 & 106 & 20.5 \\
51+ & & 21.3 \\
Socioeconomic stratification * & 75 & \\
A & 53 & 15.0 \\
B2 & 92 & 11.0 \\
C1 & 169 & 34.0 \\
C2 & 63 & 12.5 \\
D-E & 45 & 9.0 \\
\hline
\end{tabular}

Note: ${ }^{*}$ The major component of Brazilian socioeconomic stratification is indirectly measured but related to household income. Data used in this work refers to the 2019 guide developed by the Brazilian Research Companies Association (ABEP) available at http://www.abep.org/criterio-brasil (accessed on 25 November 2021). As a reference, income range, according to each social stratum is as it follows (in Brazilian ReaisBRL): Class A22,716.99 or above; Class B1-10,427.74 to 22,716.98; Class B2-5449.60 to 10,427.73; C1-3042.47 to 5449.59; C2-1805.91 to 3042.46 ; D-E-813.56 to 1805.90 .

\section{Results}

\subsection{Predisposition Regarding Sustainable Dietary Behaviours}

Initially, we submitted the dataset to an Exploratory Factor Analysis (EFA). All loadings were above 0.500 and grounded on the respective construct. In addition, we confirmed the results using Confirmatory Factor Analysis (CFA using the laavan package). The model showed adequate fit $(\chi 2=670.474, \mathrm{df}=149, p<0.01)$ and construct validity by reasonableness scores for convergent and discriminant validity. Table 3 depicts the main CFA validation indices. The diagonal axes of the correlation matrix are the square roots of the AVE. Common Method Bias was performed using a common latent factor and a marker variable, leading to less than $2.0 \%$ common method variance (Significance level: ${ }^{*} p<0.10$, ** $p<0.05, * * *<0.01$.).

Table 3. Convergent and discriminant validity.

\begin{tabular}{cccccc}
\hline & $\begin{array}{c}\text { Construct } \\
\text { Reliability (CR) }\end{array}$ & $\begin{array}{c}\text { Average Variance } \\
\text { Extracted (AVE) }\end{array}$ & $\begin{array}{c}\text { Maximum Shared } \\
\text { VarianceMSV }\end{array}$ & $\begin{array}{c}\text { Maximum } \\
\text { reliability } \\
\text { MaxR (H) }\end{array}$ & $\begin{array}{c}\text { Predisposition } \\
\text { Behaviour }\end{array}$ \\
\hline $\begin{array}{c}\text { Predisposition } \\
\text { Behaviour }\end{array}$ & 0.931 & 0.924 & 0.640 & 0.307 & 0.946 \\
Barriers & 0.848 & 0.530 & 0.307 & 0.945 & 0.814 \\
\hline
\end{tabular}

* Significance level: ${ }^{*} p<0.10,{ }^{* *} p<0.05,{ }^{* * *} p<0.01$. Square root of AVE in bold.

The predisposition to sustainable dietary behaviour was high, demonstrating fundamental advances in the relevance perception of individual and collective actions. The same results emerged specifically related to the consumption of food of animal origin (see Tables 4 and 5), which illustrates the intersection between sustainable diets and plant-based diets. We asked, "In your perspective, are the following actions important for sustainability?" (predisposition) and "Do you believe that the following actions are important for sustainability concerning eating habits?" (behaviour).

We presented several questions explaining specific eating habits related to the sustainability of the respondents. The answers concerning the following amendments showed high relevance referring to the predisposition phase, such as increasing the consumption of fruits, vegetables and greens; trying to have a diverse diet; prioritising foods rich in several nutrients; avoiding ultra-processed foods; and maintaining a low consumption of added 
sugars. Our questioning method can be described by the following questions: "In your perspective, are the following actions important for sustainability?" for predisposition and "In relation to your usual consumption of food of animal origin, have you made any of the following changes?" for behaviour.

Table 4. Questions regarding predisposition and behaviour about sustainable eating habits $(n=497)$.

\begin{tabular}{|c|c|c|}
\hline Items & $\begin{array}{c}\text { Predisposition } \\
\text { (1-7 Likert Scale) }\end{array}$ & $\begin{array}{c}\text { Behaviour } \\
\text { (1-7 Likert Scale) }\end{array}$ \\
\hline Prioritise foods naturally rich in nutrients & 5.77 & 4.89 \\
\hline Seeking to have a diversified diet & 5.81 & 5.13 \\
\hline $\begin{array}{l}\text { Maintain a caloric intake according to my needs } \\
\text { (not in excess) }\end{array}$ & 5.59 & 4.41 \\
\hline Reduce the size of food portions & 5.45 & 4.64 \\
\hline Avoid ultra-processed foods & 5.76 & 4.03 \\
\hline Preference to food consumption 'in natura' & 5.60 & 4.64 \\
\hline Maintain low sugars consumption & 5.70 & 4.01 \\
\hline Prioritise unsaturated fats over saturated fats & 5.39 & 3.86 \\
\hline $\begin{array}{l}\text { Prioritise whole cereals grains and their } \\
\text { derivatives over the refined version }\end{array}$ & 5.48 & 4.09 \\
\hline $\begin{array}{l}\text { Consumption of plant-based food in large } \\
\text { quantity and variety }\end{array}$ & 5.53 & 4.60 \\
\hline $\begin{array}{l}\text { Increase consumption of fruits, vegetables and } \\
\text { greens (leaves) }\end{array}$ & 5.90 & 5.19 \\
\hline $\begin{array}{l}\text { Increase consumption of beans, peas, lentils, } \\
\text { chickpeas and soybeans }\end{array}$ & 5.46 & 4.54 \\
\hline $\begin{array}{l}\text { Reduce the intake of tubers (potatoes } \\
\text { and cassava) }\end{array}$ & 4.69 & 3.48 \\
\hline $\begin{array}{l}\text { Maintain a food standard that meets personal, } \\
\text { cultural and traditional aspects, not only } \\
\text { nutrient needs }\end{array}$ & 5.07 & 4.09 \\
\hline
\end{tabular}

Table 5. Questions regarding predisposition and behaviour about animal-based food consumption $(n=497)$.

\begin{tabular}{lcc}
\hline \multicolumn{1}{c}{ Items } & $\begin{array}{c}\text { Predisposition } \\
\text { (1-7 Likert Scale) }\end{array}$ & $\begin{array}{c}\text { Behaviour } \\
\text { (1-7 Likert Scale) }\end{array}$ \\
\hline Reduction in animal-based food intake in general & 4.19 & 2.74 \\
Reduction in meat consumption (especially beef) & 4.38 & 3.42 \\
Reduction in processed meat consumption & 4.93 & 3.15 \\
Exclusion of red meat (beef) & 4.03 & 2.65 \\
Exclusion of processed animal-based protein & 4.84 & 3.46 \\
Replacement of meat by fish and seafood & 3.99 & 2.72 \\
Exclusion of all meat, fish, and seafood, keeping & 3.64 & 2.41 \\
eggs, milk and dairy & 3.87 & 2.50 \\
Exclusion of all animal-based protein food & & \\
\hline
\end{tabular}

\subsection{Barriers to the Adoption of Sustainable Diets}

Next, we conducted a covariance-based structural equation modelling (CB-SEM) procedure using IBM SPSS AMOS 26. After we found an acceptable model adjustment after dropping three-items $\left(\chi^{2}=438.298, \mathrm{df}=146, p<0.01, \mathrm{CFI}=0.923, \mathrm{GFI}=0.901\right.$, RMSEA $=0.064$ [0.054;0.093], Pclose $=0.000)$, we calculated the moderation effect using 1000 replications bootstrap. The direct effect of Predisposition to Behaviour towards meat intake reduction was $0.564, \mathrm{CI}=[0.493,0.635], p<0.01$. The indirect effects of both practical barriers and essential barriers were nonsignificant $(b=0-0.017, p=0.114$ and $b=0.004$, $p=0.473$, respectively). In addition, the direct effect of Predisposition to Behaviour towards sustainable diets was $0.329, \mathrm{CI}=[0.278,0.380], p<0.01$. The indirect effects of both practical 
barriers and essential barriers were nonsignificant $(b=0.012, p=0.062$ and $b=0.451$, $p=0.451$, respectively). The results are consolidated in Table 6 .

Table 6. Hypothesis testing summary.

\begin{tabular}{cccc}
\hline Hypothesis & Relationship & $\gamma \mid \mathbf{b}$ & $p$-Value \\
\hline H1a & Predisposition $\rightarrow$ Behaviours towards meat intake reduction & $\gamma=0.564$ & $<0.001$ \\
H2a & Predisposition $\rightarrow$ Behaviours towards Sustainable Diets & $\gamma=0.329$ & $<0.001$ \\
H1b & Mediation effect of practical barriers on Predisposition to meat intake & $\mathrm{b}=-0.017$ & 0.114 \\
$\mathrm{H} 1 \mathrm{c}$ & Mediation effect of essential barriers on Predisposition to meat intake & $\mathrm{b}=0.004$ & 0.473 \\
$\mathrm{H} 2 \mathrm{~b}$ & Mediation effect of practical barriers on Sustainable Diets & $\mathrm{b}=0.012$ & 0.062 \\
$\mathrm{H} 2 \mathrm{c}$ & Mediation effect of essential barriers Sustainable Diets & $\mathrm{b}=0.045$ & 0.451 \\
\hline
\end{tabular}

Since the moderating effect of practical barriers was significant at the $10 \%$ level, we performed a post hoc analysis. Using generalised linear modelling (glm and lme4 packages in R), we found a U-shaped relationship between Predisposition and Behaviour towards Sustainable Diets for respondents with medium and high levels of barrier perception (practical barriers [42]).

The differences between customers with high and low barrier perception were compared, confirming a small but significant difference in Behaviour between low practical barrier consumers $(\mathrm{Mdn}=5.14)$ and high practical barrier consumers $(\mathrm{Mdn}=5.25)$. A Wilcoxon signed-rank test showed that this difference was statistically significant, $X=-7.21, p<0.001$, with a medium to low effect size $(r=0.23)$. The behaviour of the respondents in the sample did not advance to the stage of behavioural adoption, although the previous stage (predisposition) was high. The dispersion of behaviour between the scale points was high, with more intense concentration on the average score, with no corresponding concentration, even with an increased predisposition (see Figure 2).
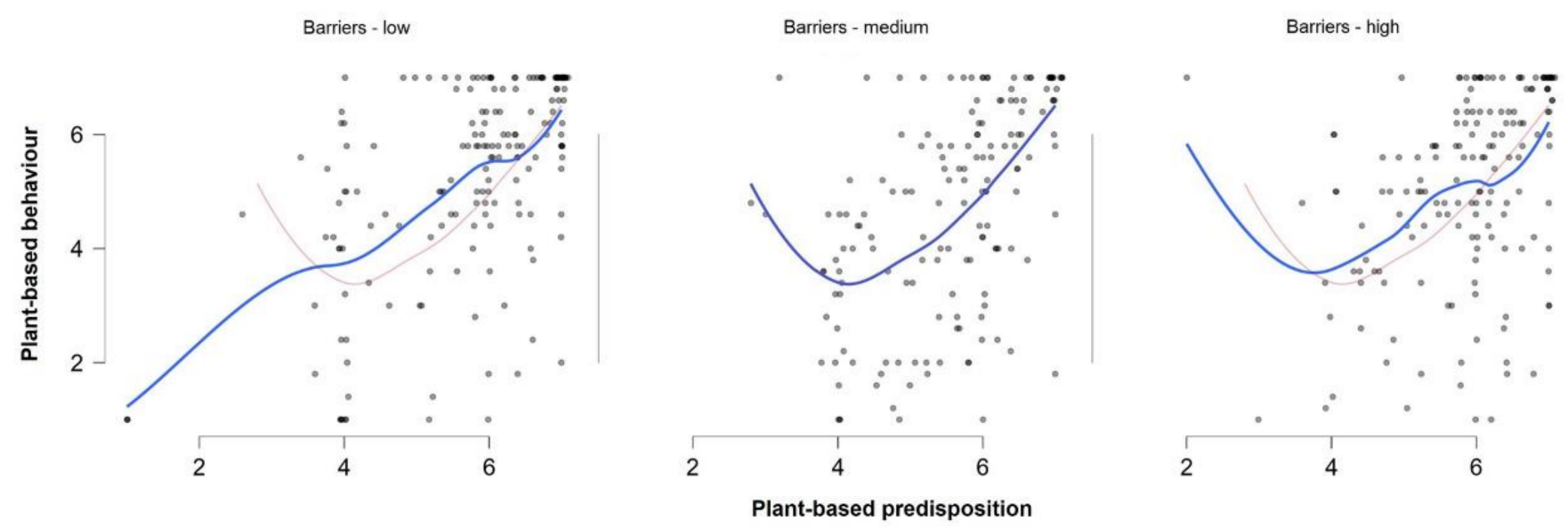

Figure 2. Predisposition and behaviour relationship considering barriers' moderating effect.

The concepts of practical barriers [42] and essential barriers [51] used in this study focused on the adoption and preparation of sustainable diets (see Table 7). Individuals perceived barriers as medium-high, with an average of $\bar{x}=4.57$ points on the modified 1 to 7 Likert point scale. The main perceived barrier to adopting a plant-based diet was the enjoyment of eating meat $(\bar{x}=5.58 ; \sigma=1.47)$, followed by the lack of information about plant-based diets $(\bar{x}=5.11 ; \sigma=1.48)$. Impediments regarding meat alternatives remained above the overall average $(\bar{x}=4.57)$, confirming that the consumption of meat also remains naturally necessary and easier than preparing no-meat meals for the Brazilian population. The frequency of shopping for fresh food and the unfamiliarity with plantbased products represented another common difficulty. On average, respondents showed higher resistance to the adoption of sustainable diets than other barriers, showing that 
the population still lacks proper knowledge on the topic. However, the barriers in this study did not seem to represent the primary drivers to moderate the relation between predisposition and behaviour change. When the barriers were at low levels (1-4 in the modified Likert scale), predisposition positively impacted behaviour, indicating that high predisposition can surpass barriers if they are low. As the barrier perception increased to medium to high levels (4.4-8) and higher levels (4.8-7), the predisposition changed in high levels of behaviours. This U-shape of the graph represents that high barrier perception can make the relationship between predisposition and behaviour less clear, regulating it negatively. We asked, "When adopting new eating habits, some aspects need to be evaluated. Do you agree that this is a reality in your decision making?" Questions were adapted by the authors for sustainable food, using Lea et al. 2006 as 'practical barriers' and Pohjolainen et al. 2015 as 'essential barriers'.

Table 7. Barriers to the adoption of new eating habits $(n=497)$.

\begin{tabular}{|c|c|c|}
\hline Items & $\begin{array}{c}\text { Mean } \\
\text { (1-7 Likert Scale) }\end{array}$ & SD * (Standard Deviation) \\
\hline I need more information about plant-based diets & 5.11 & 1.48 \\
\hline I need more information about sustainable diets & 5.37 & 1.37 \\
\hline My family/partner won't eat a plant-based diet & 4.58 & 1.66 \\
\hline My family/partner won't eat a sustainable diet & 4.55 & 1.60 \\
\hline I don't have enough willpower & 4.15 & 1.80 \\
\hline I would have to go food shopping too often & 5.12 & 1.50 \\
\hline I would get indigestion, bloating, gas or flatulence & 3.82 & 1.75 \\
\hline I don't know how to prepare plant-based meals & 4.16 & 1.83 \\
\hline I don't know how to prepare more sustainable meals & 4.26 & 1.77 \\
\hline $\begin{array}{l}\text { The plant foods I would need aren't available where } \\
\text { I shop }\end{array}$ & 4.19 & 1.61 \\
\hline $\begin{array}{l}\text { The plant foods I would need aren't available in } \\
\text { the canteen }\end{array}$ & 4.50 & 1.61 \\
\hline $\begin{array}{l}\text { The plant foods I would need aren't available in } \\
\text { my home }\end{array}$ & 4.45 & 1.59 \\
\hline I don't know what to eat instead of meat & 4.40 & 1.81 \\
\hline There is not enough choice when I eat out & 4.83 & 1.54 \\
\hline It takes too long to prepare plant-based meals & 4.13 & 1.68 \\
\hline It takes too long to prepare sustainable meals & 4.30 & 1.66 \\
\hline Eating meat is very enjoyable & 5.58 & 1.47 \\
\hline $\begin{array}{l}\text { Meat is a nutritionally necessary component } \\
\text { for humans }\end{array}$ & 4.86 & 1.61 \\
\hline I prefer foods that I am familiar with & 4.80 & 1.53 \\
\hline $\begin{array}{l}\text { It is harder to prepare good vegetarian meals than } \\
\text { meat ones }\end{array}$ & 4.32 & 1.67 \\
\hline It is harder to prepare good sustainable meals & 4.50 & 1.66 \\
\hline
\end{tabular}

\section{Discussion}

The primary aim was to confirm that practical and essential barriers prevent consumers' predisposition to change into behaviours regarding the adoption of sustainable dietary patterns and eating plant-based food. This paper identified that respondents recognised sustainable eating behaviours as highly relevant. However, practical actions are still a significant challenge. According to the Transtheoretical Model (TTM), this indicates that this population is in the early stages of the behaviour change process [12]. At that level, changes are poorly consolidated in practical actions, which we first hypothesised to relate closely to individuals' perceived barriers.

Our results raised questions on the role of psychological barriers on the levels of meat intake. Despite recognising the importance of the barriers-mainly, the enjoyment of eating meat and the lack of information about plant-based diets-these barriers did not prevent consumers from moving from the predisposition phase to the behavioural one, or from the preparation stage to action, in terms of TTM. When measuring the moderating effect of barriers to meat intake reduction (practical barriers [42] and essential barriers [51]), there was no effect on the increase in predisposition to the increase in behaviour. However, when 
measuring the moderating effect of barriers on increasing plant-based meals (sustainable diets), practical barriers were significant at $10 \%(b=0.012, p=0.062)$. So, practical barriers may have implications for changes in consumers' behaviour. These results corroborate similar recent studies. Consumers' perceived barriers regarding meat intake and plantbased meal preparations showed significant and negative effects on individual attitudes and adequate consumption [50].

In previous studies, the proposed barriers [42,51] showed a mediating relationship between predisposition and behaviour to more sustainable diets and consuming less animalbased protein that did not replicate in our sample. Consumers showed difficulties because of the enjoyment of eating meat and the lack of information regarding the preparation of plant-based meals. These results find support in previous literature [56] that discussed the cultural orientation of the Brazilian population to adopt meat and animal product derivatives into their regular daily meals. However, we could not confirm that either practical barriers [42] or essential barriers [51] prevented change in the relationship between predisposition and behaviour. We contend that consumers with lower barriers perceptions evolve in a direct relationship (higher predisposition leads to higher behaviour). As barrier perception increases, it becomes more challenging to convert predisposition to behaviour. Only when predisposition is at sufficiently high levels will we see the conversion.

There was a negative relationship of predisposition to behaviour (as expected) for small levels of predisposition for consumers with higher barrier levels. As these consumers increased predisposition, the moderating effect changed the course of the relationship, and there was a positive relationship of predisposition to behaviour (not expected). This led to a U-shaped curve on the moderating effect of barriers on the relationship of predisposition to behaviour, only when high barriers were observed. When there were low levels, there was a steady increase in behaviour given the increase in predisposition.

Further analysis is substantial and necessary to detect the factors preventing this shift from one stage to the following. The investigation of the psychometric properties of these barriers scale [42,51] using Item Response Theory (IRT) in the context of a developing country such as Brazil would confirm the measurement efficacy regarding individuals' psychological proximity to the adoption of a plant-based diet and meat intake reduction. Moreover, according to the CLT, consumers can still maintain a psychological distance to adopt plant-based dietary options. When comparing the barriers' perception regarding plant-based and sustainable diets, we observed a more incredible difficulty in approaching and identifying the concept of sustainable diets. There are currently scarce resources about sustainable diets' adoption for the local population, and results confirm the need to increase the understanding of the topic. Potential reasoning can be the low consumers' awareness when exposed to the concept of sustainable diets (i.e., ignoring that meat is part of a sustainable diet in reduced quantities, reflected in higher perceived barriers).

\section{Study Implications}

The results show implications for policymakers, academics and marketers interested in understanding the individuals' intention and behaviour to adopt both sustainable diets and plant-based dietary patterns. Recent studies $[57,58]$ reinforced the role of dietary shifts towards less meat consumption in public policy. However, the psychological distance was not a critical preventive factor in food adoption in emerging economies [59,60]. In this sense, the current study extends the previous evidence by applying CLT to food behaviour change decisions. Using psychological distance in the literature remains scarce [8]. Conceptually, this paper deepens the current theoretical approach to dietary patterns and individual perceptions, involving reducing or excluding meat consumption towards vegetarian and plant-based choices. The framework, driven by the moderation effect of perceived barriers [42,51], could not be confirmed, opening space for future research to fill the gap between the drivers from predisposition to behavioural change.

Social and cultural aspects can give some clues about the antecedents of the results. Considering the social conditions of the sample population, coming from a developing 
economy [61] can give some clues of the antecedents of the results since the studies from which barriers were obtained referred to developed countries, namely, Australia and Finland, and contradicted our analysis. In this sense, this study extends the geographic scope to LATAM on academic research for plant-based food adoption behaviour in the context of a developing country. Our results identified how the enjoyment of meat meals and the lack of information remain the fundamental barriers perceived by Brazilian individuals. Both producers and the industry of plant-based food should disseminate the plant-based approach, although it might be recognised as an immense struggle to change consumers' cultural habits. Changing such normative habits is still a hindrance to the adoption of sustainable diets and remains a challenge requiring further investigation.

Another explanation for the results is that individuals do not associate their personal choices of dietary changes with environmental consequences. This implies a significant focus on the prevention phase by changing consumers' knowledge and awareness levels. Managerial implications could include marketing campaigns to improve food literacy about plant-based diets, aiming for volume and frequency expansion. In addition, solutions must adopt the collaborative approach [13]. Other than meat reduction initiatives, increasing sustainable diet intake requires coordination from multiple stakeholders [62]. Given the hierarchical nature of the TTM and the paradox of the high importance of animal-based protein coexisting with the predisposition of more sustainable meals, meat production should adopt more sustainable procedures [63]. As demand remains high, meat analogues or cultured meat production could receive higher incentives for consumption [64]. With increased consumer awareness and responsiveness to the required behaviour (psychological proximity), additional measures towards sustainable diets will be easier to progress from contemplation to action (such as reducing meat intake).

The impacts of COVID-19 were not addressed in our framework, since the data gathering crossed the beginning of the pandemic. Recent research evaluated the COVID-19 pandemic's impact on food-related dimensions and detected no significant dietary change in consumer preferences [65]. Meat and bakery products emerged as being substituted by fruits and vegetables after the crisis [66]. Families cook more and buy more from local producers, and these dietary patterns might last in the years to come [67]. In Brazil, no significant change in local households during the pandemic of COVID-19 was reported [68]. However, social isolation revealed that food waste and shopping habits are linked [69], worsening food security for long periods in developing countries [70].

The current study is limited to the geographic region of Brazil, especially to Sao Paulo state, the most populous and wealthiest state in Brazil. Further research should include other regions to gain a more comprehensive understanding of consumers' reasons for and against the adoption of plant-based and sustainable diets. Using an online consumer panel is also a concern for the ecological validity of the results. In addition, similar research in neighbouring countries which share cultural, and to some extent, geographical, similarities with the southeastern Brazilian region could allow scholars to develop a regionally grounded profile of the sustainable diet concept and consuming patterns. In addition, age demographic data could also open new avenues for researching intergenerational marketing fields. Future research should include less urbanised and more rural areas, identifying more context-specific motives, barriers, awareness, and intentions. Finally, conducting similar studies with a larger sample and including other socioeconomic variables, such as marital status and level of education, could assist future research in developing targeted strategies to induce further demand for such food items among different segments of a consumer market. At last, we encourage researchers to evaluate the impact of COVID-10 in the causal-effect model proposed in our study.

\section{Conclusions}

This study used CLT as a framework to build consumers' decision-making process toward plant-based dietary adoption. Specifically, it focused on the relationship between predisposition and behaviour change by incorporating barriers to moderation. We tested 
the theoretical framework in a survey of 497 individuals in Brazil. Despite recognising the importance of the barriers-mainly the enjoyment of eating meat and the lack of information about plant-based diets-these barriers do not alter consumers from moving from the predisposition phase to the behavioural one or from the preparation stage to action in terms of TTM.

Consumers with higher barrier levels indicated a negative relationship with small levels of predisposition to behaviour (as expected). As these consumers increased their predisposition, the moderating effect changed the course of the relationship, and there was a positive relationship of predisposition to behaviour (not expected). To explain this pattern, a more comprehensive study on the barriers is still necessary. This would guarantee the identification of barriers in a more assertive way, which allows for the elaboration of actions in the individual, collective and political levels. In this way, it would be possible to promote healthier and more sustainable dietary patterns, marked by the increase in plant-based consumption.

Supplementary Materials: The following are available online at https:/ /www.mdpi.com/article/10 $.3390 /$ su14042199/s1, The questions and answers used in the study.

Author Contributions: Conceptualisation, C.E.L., N.M.N.-G. and R.B.; methodology, C.E.L., N.M.N.G., R.B., L.O.C., F.P.M. and L.B.L.; software, C.E.L.; validation, C.E.L., N.M.N.-G., R.B., L.O.C., F.P.M. and L.B.L.; formal analysis, C.E.L., N.M.N.-G., R.B., L.O.C., F.P.M. and L.B.L.; investigation, C.E.L.; resources, C.E.L.; data curation, C.E.L.; writing—original draft preparation, C.E.L., N.M.N.-G., R.B., L.O.C., F.P.M. and L.B.L.; writing-review and editing, C.E.L., N.M.N.-G., R.B., L.O.C., F.P.M. and L.B.L.; visualization, C.E.L.; supervision, C.E.L.; project administration, C.E.L.; funding acquisition, C.E.L. All authors have read and agreed to the published version of the manuscript.

Funding: This research was funded by the World Wildlife Fund for Nature-WWF-Brazil, CON 001765. The APC was funded by the Research Project Pay (RPP) Program from the Getulio Vargas Foundation (FGV EAESP). Prof. Liboni and Cezarino also acknowledge CNPq for their productivity grant that enables their dedication to research.

Institutional Review Board Statement: The study was conducted according to the guidelines of the Declaration of Helsinki and approved by the Ethics Committee of the Getulio Vargas Foundation (FGV) (protocol code 135/2021, approval date 25 June 2021, issue date 12 July 2021).

Informed Consent Statement: Informed consent was obtained from all respondents involved in the study using an opt-in button in the survey. The consumer panel company anonymised all individual information.

Data Availability Statement: The data presented in this study are available on request from the corresponding author. The data are not publicly available due to proprietary issues from the funding organisations.

Acknowledgments: The authors would like to thank the four reviewers for their insightful and valuable comments. The authors are grateful to MindMiners and WWF-Brazil for their support along the publication journey.

Conflicts of Interest: The first author acted as a consultant to WWF-Brazil.

\section{References}

1. Vermeir, I.; Weijters, B.; De Houwer, J.; Geuens, M.; Slabbinck, H.; Spruyt, A.; Van Kerckhove, A.; Van Lippevelde, W.; De Steur, H.; Verbeke, W. Environmentally sustainable food consumption: A review and research agenda from a goal-directed perspective. Front. Psychol. 2020, 11, 1603. [CrossRef]

2. FAO-Food and Agriculture Organization of the United Nations. Sustainable Diets and Biodiversity: Directions and Solutions for Policy, Research and Action. In Proceedings of the International Scientific Symposium Biodiversity and Sustainable Diets United Against Hunger, Rome, Italy, 3-5 November 2010; FAO: Rome, Italy, 2010.

3. Pocol, C.B.; Marinescu, V.; Amuza, A.; Cadar, R.L.; Rodideal, A.A. Sustainable vs. unsustainable food consumption behaviour: A study among students from Romania, Bulgaria, and Moldova. Sustainability 2020, 12, 4699. [CrossRef]

4. FAO-Food and Agriculture Organization of the United Nations; WHO-World Health Organization. Sustainable Healthy Diets_Guiding Principles; FAO: Rome, Italy, 2019. 
5. Lacasse, K. Can't hurt, might help: Examining the spillover effects from purposefully adopting a new pro-environmental behavior. Environ. Behav. 2019, 51, 259-287. [CrossRef]

6. Giesen, R.; Leenheer, J. Towards more interactive and sustainable food retailing: An empirical case study of the supermarket of the future. Int. J. Retail Distrib. Manag. 2018, 47, 201-218. [CrossRef]

7. Dagevos, H.; Voordouw, J. Sustainability and meat consumption: Is reduction realistic? Sustain. Sci. Pract. Policy 2013, 9, 60-69. [CrossRef]

8. Loy, L.S.; Spence, A. Reducing, and bridging, the psychological distance of climate change. J. Environ. Psychol. 2020, 67, 1-8. [CrossRef]

9. Trope, Y.; Liberman, N.; Wakslak, C. Construal levels and psychological distance: Effects on representation, prediction, evaluation, and behavior. J. Consum. Psychol. 2007, 17, 83-95. [CrossRef]

10. Leiser, D.; Azar, O.H.; Hadar, L. Psychological construal of economic behavior. J. Econ. Psychol. 2008, 29, 762-776. [CrossRef]

11. Prochaska, J.O.; Redding, C.A.; Evers, K.E. The transtheoretical model and stages of change. In Health Behavior: Theory, Research, and Practice; Glanz, K., Rimer, B.K., Viswanath, K., Eds.; Jossey-Bass Inc.: San Francisco, CA, USA, 2015; pp. 97-121.

12. Hashemzadeh, M.; Rahimi, A.; Zare-farashbandi, F.; Alavi-Naeini, A.M.; Daei, A. Transtheoretical model of health behavioral change: A systematic review. Iran. J. Nurs. Midwifery Res. 2019, 24, 83-90.

13. Cousins, P.D.; Lawson, B.; Petersen, K.J.; Fugate, B. Investigating green supply chain management practices and performance. Int J. Oper. Prod. Manag. 2019, 39, 5-10. [CrossRef]

14. Tobler, C.; Visschers, V.; Siegrist, M. Eating green. Consumers' willingness to adopt ecological food consumption behaviors. Appetite 2011, 57, 674-682. [CrossRef]

15. Weibel, C.; Ohnmacht, T.; Schaffner, D.; Kossmann, K. Reducing individual meat consumption: An integrated phase model approach. Food Qual. Prefer. 2019, 73, 8-18. [CrossRef]

16. Schandl, H.; Hatfield-Dodds, S.; Wiedmann, T.; Geschke, A.; Cai, Y.; West, J.; Newth, D.; Baynes, T.; Lenzen, M.; Owen, A. Decoupling global environmental pressure and economic growth: Scenarios for energy use, materials use and carbon emissions. J. Clean. Prod. 2016, 132, 45-56. [CrossRef]

17. Falchetta, G.; Golinucci, N.; Noussan, M.; Rocco, M.V. Environmental and Energy Implications of Meat Consumption Pathways in Sub-Saharan Africa; Working Paper No. 5.2021; FEEM: Milan, Italy, 2021.

18. Moberg, E.; Karlsson Potter, H.; Wood, A.; Hansson, P.A.; Röös, E. Benchmarking the Swedish diet relative to global and national environmental targets-Identification of indicator limitations and data gaps. Sustainability 2020, 12, 1407.

19. Hamm, M.; Frison, E.; Pahlen, M.C. Human Health, Diets, and Nutrition: Missing Links in Eco-Agri-Food Systems; Scientific and Economic Foundations Report; TEEB for Agriculture and Food: Geneva, Switzerland, 2018.

20. Cobiac, L.; Irz, X.; Leroy, P.; Réquillart, V.; Scarborough, P.; Soler, L.G. Accounting for consumers' preferences in the analysis of dietary recommendations. Eur. J. Clin. Nutr. 2019, 73, 1033-1039. [CrossRef]

21. Graça, J.; Calheiros, M.M.; Oliveira, A. Attached to meat? (Un)willingness and intentions to adopt a more plant-based diet. Appetite 2015, 95, 113-125. [CrossRef]

22. Macdiarmid, J.; Douglas, F.; Campbell, J. Eating like there's no tomorrow: Public awareness of the environmental impact of food and reluctance to eating less meat as part of a sustainable diet. Appetite 2015, 96, 487-493. [CrossRef]

23. Sanchez-Sabate, R.; Badilla-Briones, Y.; Sabaté, J. Understanding attitudes towards reducing meat consumption for environmental reasons. A qualitative synthesis review. Sustainability 2019, 11, 6295. [CrossRef]

24. Clonan, A.; Wilson, P.; Swift, J.; Leibovici, D.; Holdsworth, M. Red and processed meat consumption and purchasing behaviours and attitudes: Impacts for human health, animal welfare and environmental sustainability. Public Health Nutr. 2015, 18, $2446-2456$. [CrossRef]

25. Sanchez-Sabate, R.; Sabaté, J. Consumer attitudes towards environmental concerns of meat consumption: A systematic review. Int. J. Environ. Res. Public Health 2019, 16, 1220. [CrossRef]

26. Lacroix, K. Comparing the relative mitigation potential of individual pro-environmental behaviors. J. Clean. Prod. 2018, 195, 1398-1407. [CrossRef]

27. Spence, A.; Poortinga, W.; Pidgeon, N. The psychological distance of climate change. Risk Anal. 2012, 32, 957-972. [CrossRef]

28. Malagón-Zaldua, E.; Begiristain, Z.M.; Oñederra, A. Measuring the economic impact of farmers' markets on local economies in the Basque country. Agriculture 2018, 8, 10. [CrossRef]

29. Westbrook, G.; Angus, A. Top 10 Global Consumer Trends 2020; Euromonitor International: London, UK, 2020.

30. Sihvonen, J.; Luomala, H. Hear what I appreciate: Activation of consumption motives for healthier food choices across different value segments. Int. Rev. Retail. Distrib. Consum. Res. 2017, 27, 502-514. [CrossRef]

31. Sáez-Almendros, S.; Obrador, B.; Bach-Faig, A.; Serra-Majem, L. Environmental footprints of Mediterranean versus Western dietary patterns: Beyond the health benefits of the Mediterranean diet. Environ. Health 2013, 12, 118. [CrossRef] [PubMed]

32. Wood, R.; Moran, D.; Stadler, K.; Ivanova, D.; Steen-Olsen, K.; Tisserant, A.; Hertwich, E.G. Prioritising consumption-based carbon policy based on the evaluation of mitigation potential using input-output methods. J. Ind. Ecol. 2018, 22, 540-552. [CrossRef]

33. Tukker, A.; Goldbohm, R.A.; de Koning, A.; Verheijden, M.; Kleijn, R.; Wolf, O.; Dominguez, I.P.; Rueda-Cantuche, J.M. Environmental impacts of changes to healthier diets in Europe. Ecol. Econ. 2011, 70, 1776-1788. [CrossRef]

34. Elhoushy, S. Consumers' sustainable food choices: Antecedents and motivational imbalance. Int. J. Hosp. Manag. 2020, 89, 2. [CrossRef] 
35. Sadhukhan, J.; Dugmore, T.I.; Matharu, A.; Martinez-Hernandez, E.; Aburto, J.; Rahman, P.K.; Lynch, J. Perspectives on "game changer" global challenges for sustainable 21st century: Plant-based diet, unavoidable food waste biorefining, and circular economy. Sustainability 2020, 12, 1976. [CrossRef]

36. Geipel, J.; Hadjichristidis, C.; Klesse, A.K. Barriers to sustainable consumption attenuated by foreign language use. Nat. Sustain. 2018, 1, 31-33. [CrossRef]

37. Willett, W.; Rockström, J.; Loken, B.; Springmann, M.; Lang, T.; Vermeulen, S.; Garnett, T.; Tilman, D.; DeClerck, F.; Wood, A.; et al Food in the Anthropocene: The EAT-Lancet Commission on healthy diets from sustainable food systems. Lancet 2019, 395, 447-492. [CrossRef]

38. Derbyshire, E.J. Flexitarian diets and health: A review of the evidence-based literature. Front. Nutr. 2017, 3, 55-65. [CrossRef]

39. Mathieu, S.; Dorard, G. Vegetarianism and veganism lifestyle: Motivation and psychological dimensions associated with selective diet. Presse Med. 2016, 45, 726-733. [CrossRef]

40. Carrus, G.; Pirchio, S.; Mastandrea, S. Social-cultural processes and urban affordances for healthy and sustainable food consumption. Front. Psychol. 2018, 9, 2407. [CrossRef]

41. Springmann, M.; Wiebe, K.; Mason-D'Croz, D.; Sulser, T.; Rayner, M.; Scarborough, P. Health and nutritional aspects of sustainable diet strategies and their association with environmental impacts: A global modelling analysis with country-level detail. Lancet Planet. Health 2018, 2, 451-461. [CrossRef]

42. Lea, E.J.; Crawford, D.; Worsley, A. Public views of the benefits and barriers to the consumption of a plant-based diet. Eur. J. Clin. Nutr. 2006, 60, 828-837. [CrossRef]

43. Ahmed, S.; Downs, S.; Fanzo, J. Advancing an integrative framework to evaluate sustainability in National Dietary Guidelines. Front. Sustain. Food Syst. 2019, 3, 76. [CrossRef]

44. Brink, E.; van Rossum, C.; Postma-Smeets, A.; Stafleu, A.; Wolvers, D.; van Dooren, C.; Toxopeus, I.; Buurma-Rethans, E.; Geurts, M.; Ocké, M. Development of healthy and sustainable food-based dietary guidelines for the Netherlands. Public Health Nutr. 2019, 22, 2419-2435. [CrossRef]

45. Meltzer, H.M.; Brantsæter, A.L.; Trolle, E.; Eneroth, H.; Fogelholm, M.; Ydersbond, T.A.; Birgisdottir, B.E. Environmental sustainability perspectives of the Nordic diet. Nutrients 2019, 11, 2248. [CrossRef]

46. Ministry of Health of Brazil. Dietary Guidelines for the Brazilian Population; Ministry of Health: Brasília, Brazil, 2014.

47. Burger, J.M.; Bell, H.; Harvey, K.; Johnson, J.; Stewart, C.; Dorian, K.; Swedroe, M. Nutritious or delicious? The effects of descriptive norm information on food choice. J. Soc. Clin. Psychol. 2010, 29, 228-242. [CrossRef]

48. Corallo, A.; Latino, M.E.; Menegoli, M.; Spennato, A. A survey to discover current food choice behaviors. Sustainability 2019, 11, 5041. [CrossRef]

49. Sobal, J.; Bisogni, C.A. Constructing food choice decisions. Ann. Behav. Med. 2009, 28, S37-S46. [CrossRef]

50. Cheah, I.; Sadat Shimul, A.; Liang, J. Drivers and barriers toward reducing meat consumption. Appetite 2020, $149,104636$. [CrossRef] [PubMed]

51. Pohjolainen, P.; Vinnari, M.; Jokinen, P. Consumers' perceived barriers to following a plant-based diet. Br. Food J. 2015, 117, 1150-1167. [CrossRef]

52. Steptoe, A.; Pollard, T.M.; Wardle, J. Development of a measure of the motives underlying the selection of food: The food choice questionnaire. Appetite 1995, 25, 267-284. [CrossRef] [PubMed]

53. Khandpur, N.; Quinta, F.P.; Jaime, P.C. A quantitative test of the face validity of behavior-change messages based on the Brazilian Dietary Guidelines. Nutr. J. 2021, 20, 1-10. [CrossRef] [PubMed]

54. Armstrong, B.; Reynolds, C.; Bridge, G.; Oakden, L.; Wang, C.; Panzone, L.; Rivera, X.S.; Kause, A.; Ffoulkes, C.; Krawczyk, C.; et al. How does citizen science compare to online survey panels? A comparison of food knowledge and perceptions between the zooniverse, prolific and qualtrics UK panels. Front. Sustain. Food Syst. 2021, 4, 306-314. [CrossRef]

55. Hair, J.F.; Black, W.C.; Babin, B.J.; Anderson, R.E. Multivariate Data Analysis, 8th ed.; Pearson Education Limited: Harlow, UK, 2019.

56. Cantilino, A.; Carvalho, J.A.; Maia, A.; Albuquerque, C.; Cantilino, G.; Botelho Sougey, E. Translation, validation, and cultural aspects of postpartum depression screening scale in Brazilian Portuguese. Transcult. Psychiatry 2007, 44, 672-684. [CrossRef]

57. Chandler, J.; Rosenzweig, C.; Moss, A.J.; Robinson, J.; Litman, L. Online panels in social science research: Expanding sampling methods beyond Mechanical Turk. Behav. Res. Methods 2019, 51, 2022-2038. [CrossRef]

58. Verain, M.C.D.; Dagevos, H.; Antonides, G. Sustainable food consumption; Product choice or curtailment? Appetite 2015, 91, 375-384. [CrossRef]

59. Blanco-Murcia, L.; Ramos-Mejía, M. Sustainable diets and meat consumption reduction in emerging economies: Evidence from Colombia. Sustainability 2019, 11, 6595. [CrossRef]

60. Fardet, A.; Thivel, D.; Gerbaud, L.; Rock, E. A sustainable and global health perspective of the dietary pattern of French population during the 1998-2015 period from INCA surveys. Sustainability 2021, 13, 7433. [CrossRef]

61. Basha, M.B.; Lal, D. Indian consumers' attitudes towards purchasing organically produced foods: An empirical study. J. Clean. Prod. 2019, 215, 99-111. [CrossRef]

62. Yadav, R.; Pathak, G.S. Intention to purchase organic food among young consumers: Evidence from a developing nation. Appetite 2016, 96, 122-128. [CrossRef]

63. HDI-Human Development Reports. Human Development Index 2019. Available online: http://hdr.undp.org/en/countries (accessed on 10 August 2021). 
64. Austgulen, M.H. Environmentally sustainable meat consumption: An analysis of the Norwegian public debate. J. Consum. Policy 2014, 37, 45-66. [CrossRef]

65. Hirvonen, K.; de Brauw, A.; Abate, G.T. Food consumption and food security during the COVID-19 pandemic in Addis Ababa. Am. J. Agric. Econ. 2021, 103, 772-789. [CrossRef]

66. Celik, B.; Dane, S. The effects of COVID-19 pandemic outbreak on food consumption preferences and their causes. J. Res. Med. Dent. Sci. 2020, 8, 169-173.

67. Dumitras, D.E.; Harun, R.; Arion, F.H.; Chiciudean, D.I.; Kovacs, E.; Oroian, C.F.; Porutiu, A.; Muresan, I.C. Food consumption patterns in Romania during the COVID-19 pandemic. Foods 2021, 10, 2712. [CrossRef]

68. Schmitt, V.G.H.; Cequea, M.M.; Neyra, J.M.V.; Ferasso, M. Consumption behaviour and residential food waste during the COVID-19 pandemic outbreak in Brazil. Sustainability 2021, 13, 3702. [CrossRef]

69. Cequea, M.M.; Vásquez Neyra, J.M.; Schmitt, V.G.H.; Ferasso, M. Household food consumption and wastage during the covid-19 pandemic outbreak: A comparison between Peru and Brazil. Sustainability 2021, 13, 7583. [CrossRef]

70. Zidouemba, P.R.; Kinda, S.R.; Ouedraogo, I.M. Could COVID-19 worsen food insecurity in Burkina Faso? Eur. J. Dev. Res. 2020, 32, 1379-1401. [CrossRef] [PubMed] 